\title{
KADAR INSULIN-LIKE GROWTH FACTOR-1 (IGF-1) AIR SUSU IBU DAN HUMAN BETA DEFENSIN-2 (HBD-2) FESES TERHADAP LUARAN KLINIS NEONATUS
}

\author{
Bayu Kurniawan $^{\star \varpi}$, Anik Puryatni ${ }^{\star *}$, Hidayat Sujuti ${ }^{\star * *}$
}

\begin{abstract}
Abstrak
Prevalensi sepsis neonatal meningkat $40 \%$ pada prematuritas. American Academy of Pediatrics merekomendasikan pemberian ASI pada neonatus prematur. ASI berperan pada pertahanan pencernaan melalui growth factors, antimicrobial protein and peptides, dan sitokin. Growth factors ASI yang signifikan pada maturitas usus neonatus adalah IGF-1 yang memberikan efek protektif selama peradangan. HBD-2 adalah biomarker tinja non-invasif yang teridentifikasi pada feses neonates dan berkaitan dengan inflamasi. Penelitian ini untuk mengetahui kadar IGF-1 ASI transisi dan HBD-2 feses neonatus terhadap luaran klinis neonatus. Sampel penelitian adalah 24 pasangan ibu dan neonatus yang dikumpulkan pada Bulan JuniAgustus 2019 di ruang neonatologi RS. Dr. Saiful Anwar Malang. Sampel dikelompokkan menjadi 4 kelompok berdasarkan usia kehamilan. Karakteristik pasangan ibu-neonatus dan luaran klinis neonatus dicatat. Kadar IGF-1 ASI transisi dan HBD-2 feses diukur dengan metode ELISA, dan dianalisis secara statistik. Hasil menunjukkan perbedaan bermakna rata-rata kadar IGF-1 ASI transisi dan HBD-2 feses dari tiap kelompok ( $p<0,05)$; kadar IGF-1 ASI transisi berbanding lurus dengan usia kehamilan $(r=0,611)$ dan sebaliknya dengan kadar HBD-2 feses $(r=-0,725)(p<0,05)$. Terdapat perbedaan kadar HBD-2 feses yang bermakna pada luaran klinis patologis neonatus (feeding intolerance, enterokolitis nekrotikan, dan penggunaan ventilasi mekanik) ( $p<0,05)$. Disimpulkan bahwa prematuritas menunjukkan kadar IGF-1 ASI transisi yang rendah dan peningkatan kadar HBD-2 feses, sehingga meningkatkan risiko infeksi saluran pencernaan. HBD-2 feses juga terbukti berperan sebagai biomarker inflamasi saluran pencernaan neonatus.
\end{abstract}

Kata kunci: ASI, HBD-2, IGF-1, neonatus.

\section{LEVELS OF HUMAN MILK'S INSULIN-LIKE GROWTH FACTOR-1 (IGF-1) AND FECAL HUMAN BETA DEFENSIN-2 (HBD-2) AGAINST NEONATAL CLINICAL OUTCOME}

\begin{abstract}
The prevalence of neonatal sepsis increases to $40 \%$ in prematurity. American Academy of Pediatrics recommends breastfeeding in preterm neonates. Human milk contributes to the defense function of the digestive tract, through the role of growth factors, antimicrobial protein-peptides, and cytokines. Human milk's growth factor that has a significant role in neonatal intestinal maturity is IGF-1 which gives a protective effect during inflammation. HBD-2 is a non-invasive stool biomarker identified in neonatal fecal associated with inflammation. This study was to determine the levels of transitional human milk's IGF-1 and fecal HBD-2 against neonatal clinical outcomes. The sample was 24 pairs of mothers and neonates who were collected from June to August 2019 in the neonatology ward Dr. Saiful Anwar Public Hospital Malang. Samples were grouped according to gestational age. Characteristics pairs of mother-neonates and clinical outcomes were recorded. Levels of transitional human milk's IGF-1 and fecal HBD-2 were measured by ELISA, then statistical analysis was performed. The results showed that there were significant mean differences of human milk's IGF-1 and fecal HBD-2 from each group ( $p<0.05)$; human milk's IGF-1 levels was directly proportional to gestational age $(r=0.611)$ and vice versa of fecal HBD-2 levels $(r=-0.725)(p<$ 0.05). There were significant differences in fecal HBD-2 levels in neonatal clinical outcomes by feeding intolerance, necrotizing enterocolitis, and mechanical ventilation $(p<0.05)$. It was concluded that prematurity showed low levels of transitional human milk's IGF-1 and increased levels of fecal HBD-2, thereby increasing the risk of gastrointestinal infections. Fecal HBD-2 has a potential role as an inflammatory biomarker of the neonatal digestive tract.
\end{abstract}

Keywords: human milk, HBD-2, IGF-1, neonates.

* Program Magister (S2) IImu Biomedik, Fakultas Kedokteran, Universitas Brawijaya

${ }^{* *}$ Departmen Ilmu Kesehatan Anak, Fakultas Kedokteran, Universitas Brawijaya-RSUD. Dr. Saiful Anwar Malang

${ }^{* * \star}$ Departemen Biokimia-Biomolekuler, Fakultas Kedokteran, Universitas Brawijaya

E-mail: bayukurniawanmdpaed@gmail.com 


\section{Pendahuluan}

American Academy of Pediatrics (AAP) merekomendasikan ASI lebih superior dibandingkan susu formula untuk pemberian asupan enteral pada neonatus prematur. ${ }^{1}$ Keuntungan pemberian ASI adalah berkurangnya angka kejadian enterokolitis nekrotikan (EKN), sepsis, mortalitas, meningkatkan toleransi pemberian makan, pencapaian awal pemberian makanan enteral secara penuh, pertumbuhan dan perkembangan susunan saraf dalam jangka panjang yang lebih baik. ${ }^{1,2}$ Kelahiran prematur adalah isu global yang signifikan, mempengaruhi $10 \%$ kelahiran hidup di seluruh dunia. ${ }^{3}$ Sepsis neonatal banyak terjadi pada neonatus prematur, prevalensi sepsis neonatal meningkat sampai $40 \%$ pada neonatus dengan usia kehamilan $<28$ minggu (extremely preterm infants).4 Bukti klinis menunjukkan bahwa etiologi patogen sepsis neonatal terjadi karena translokasi bakteri dari saluran pencernaan neonatus prematur. ${ }^{5}$

Kelangsungan hidup patogen yang menyebabkan sepsis dipengaruhi secara berbeda oleh kadar protein antimikroba pada ASI, dan korelasi antara usia kehamilan dengan kadar antimicrobial protein and peptides (AMP). ${ }^{6-7} \mathrm{Hal}$ ini menimbulkan pertanyaan apakah ASI dari ibu dengan neonatus prematur memiliki kadar growth factors, AMP, dan sitokin yang lebih rendah dibandingkan dengan ASI dari ibu dengan neonatus aterm, sehingga berkontribusi terhadap peningkatan risiko sepsis pada populasi neonatus prematur. Komposisi protein, faktor imunitas, growth factors, AMP, dan sitokin pada ASI bervariasi dan dipengaruhi oleh beberapa faktor seperti usia ibu, cara persalinan, fase laktasi, volume susu yang dihasilkan, merokok, indeks massa tubuh, paritas, dan infeksi ibu. Banyak dari parameter maternal ini juga merupakan faktor risiko yang terkait dengan kelahiran prematur, dan hubungan antara kelahiran prematur dan komposisi ASI membutuhkan penelitian lebih lanjut. 8-12

ASI mengandung sejumlah peptida biologis aktif termasuk growth factors dalam jumlah bermakna, yang memilki efek biologis terhadap saluran pencernaan, pembuluh darah, susunan saraf, dan sistem endokrin. Growth factors dalam ASI yang diketahui memilki peran signifikan pada maturitas usus neonatus adalah insulin-like growth factor-1 (IGF-1). ${ }^{13}$

Enterokolitis nekrotikan merupakan salah satu morbiditas utama pada neonatus prematur, namun diagnosis definitif sulit ditegakkan. ${ }^{14}$ Salah satu upaya yang dilakukan untuk menurunkan angka morbiditas dan mortalitas akibat infeksi saluran pencernaan yakni adanya biomarker non-invasif, biomarker feses menjadi salah satu pilihan pemeriksaan non-invasif. ${ }^{15,16}$ Beberapa peptida teridentifikasi pada mekonium dan feses neonatus pada minggu pertama kehidupan, salah satunya human beta defensin. Human beta defensin yang disekresi pada epitel saluran pencernaan dan berhubungan dengan reaksi inflamasi yakni human beta defensin-2 (HBD-2). ${ }^{15}$

Penelitian kadar HBD-2 feses pada neonatus prematur dihubungkan dengan riwayat pemberian nutrisi enteral masih terdapat hasil yang bertentangan. Avula et al., 2017 menunjukkan bahwa HBD-2 feses terekspresi rendah pada inflamasi gastrointestinal berat, penelitian lain menunjukkan peningkatan HBD-2 pada mukosa kolon yang mengalami inflamasi. ${ }^{14-16}$ Corebima, 2017 membuktikan HBD-2 feses mampu merefleksikan kejadian inflamasi intestinal pada neonatus prematur yang mengonsumsi ASI maupun susu formula di usia empat belas hari. ${ }^{17}$ Penelitian yang mengkaji kadar IGF-1 sebagai growth factors pada ASI neonatus prematur pada tahapan laktasi dan kadar HBD-2 feses sebagai biomarker inflamasi non-invasif masih terbatas. 
Oleh karena itu, perlu dilakukan penelitian tentang kadar IGF-1 ASI transisi dan HBD-2 feses terhadap luaran klinis neonatus.

\section{Bahan dan Metode}

Penelitian ini merupakan penelitian analitik menggunakan rancangan studi cross sectional. Dilakukan di Rumah Sakit Umum Daerah Dr. Saiful Anwar (RSSA) dan Laboratorium Fisiologi Fakultas Kedokteran Universitas Brawijaya Malang pada Bulan JuniAgustus 2019.

Sampel penelitian yaitu pasangan ibu dengan neonatus aterm (usia kehamilan 37 sampai $<42$ minggu) atau neonatus prematur (usia kehamilan $<37$ minggu) dengan berat badan lahir normal ${ }^{32} .500$ gram (BBLN) atau berat badan lahir rendah $<2.500$ gram (BBLR), yang memenuhi kriteria inklusi. Kriteria inklusi sampel penelitian adalah; (1) pasangan ibu dan neonatus aterm/prematur yang dirawat di RSSA dan mendapatkan nutrisi ASI; (2) Neonatus aterm/prematur dengan skor APGAR $>5$ pada menit kelima, tanpa kelainan kongenital atau kelainan bedah pada saluran pencernaan; dan (3) lbu mengijinkan bayinya diikutsertakan dalam penelitian setelah diberikan penjelasan (informed consent). Bahan penelitian yang digunakan adalah ASI transisi dan feses neonatus dari ibu dengan neonatus aterm/ prematur, yang dikumpulkan pada hari ke-10 pasca persalinan. ASI transisi/peralihan adalah ASI post-kolostrum yang disekresikan oleh payudara ibu mulai hari ke-4 sampai dengan 10-14 hari post-natal dengan komposisi ASI menyerupai ASI matur yang disekresikan payudara ibu setelah periode ASI transisi.

Data karakteristik sampel penelitian (pasangan ibu dengan neonatus aterm/ prematur) direkam dalam bentuk tabel dan dilakukan analisis statistik. Kadar IGF-1 ASI transisi dan kadar HBD-2 feses neonatus diukur dengan teknik enzyme-linked immunosorbent assay (ELISA), hasil yang diperoleh adalah skala data numerik untuk dilakukan analisis statistik. Data numerik kadar IGF-1 ASI transisi dan HBD-2 feses neonatus dilakukan uji normalitas ShapiroWilk sebagai syarat uji statistik parametrik. Bila data sampel penelitian terdistribusi normal, dilakukan uji one-way ANOVA (analysis of variance) dan bila data sampel tidak terdistribusi normal, dilakukan uji Kruskal Wallis, untuk melihat perbedaan kadar IGF-1 ASI transisi dan kadar HBD-2 feses neonatus dari tiap-tiap kelompok penelitian. Untuk membuktikan korelasi antar variabel, dilakukan uji korelasi Pearson (data terdistribusi normal). Penelitian ini telah disetujui oleh tim kelayakan etik RSSA (no. 400/21/K.3/302/2018).

\section{Hasil}

\section{Karakteristik Sampel Penelitian}

Didapatkan 24 sampel penelitian pasangan ibu dan neonatus yang terbagi dalam empat kelompok penelitian; kelompok pertama adalah pasangan ibu dengan neonatus usia kehamilan $37-<42$ minggu, kelompok kedua adalah kelompok pasangan ibu dengan neonatus usia kehamilan $32-<37$ minggu, kelompok ketiga adalah kelompok pasangan ibu dengan neonatus usia kehamilan 28-<32 minggu, dan kelompok keempat adalah kelompok pasangan ibu dengan neonatus usia kehamilan <28 minggu. Masing-masing kelompok penelitian terdiri dari 6 pasangan ibu-neonatus, pada penelitian ini 18 sampel penelitian adalah neonatus prematur (usia kehamilan $<37$ minggu) dan 6 sampel penelitian adalah neonatus aterm (usia kehamilan $37-<42$ minggu).

Karakteristik sampel penelitian yang diamati adalah karakteristik ibu dan neonatus. Karakteristik ibu yaitu usia, indeks massa tubuh, pendidikan, pekerjaan, paritas, perokok aktif, riwayat pre-eklampsia/eklampsia, riwayat preterm premature rupture of membrane/premature rupture of membrane, riwayat korioamnionitis. 
Karakteristik neonatus (jenis kelamin, cara lahir, usia kehamilan, berat badan lahir, skor Apgar, dan keluaran klinis insiden feeding intolerance, enterokolitis nekrotikan/EKN, neonatal sepsis/late onset sepsis, penggunaan ventilasi mekanik). Data karakteristik sampel penelitian secara rinci ditampilkan pada Tabel 1.

Hasil analisis statistik menunjukkan tidak terdapat perbedaan yang signifikan pada empat kelompok penelitian berdasarkan karakteristik ibu (usia, indeks massa tubuh, status pekerjaan, paritas, riwayat kehamilan dengan korioamnionitis dan preterm premature rupture of membrane/premature rupture of membrane $>18$ jam). Namun, pada ibu perokok aktif dan riwayat kehamilan ibu dengan pre-ekalmpsia/eklampsia memberikan perbedaan yang signifikan secara statistik di antara empat kelompok penelitian (nilai $p<$ 0,05).

Data karakteristik neonatus yang menjadi sampel penelitian menunjukkan perbedaan yang signifikan pada empat kelompok penelitian berdasarkan cara lahir, berat badan lahir, skor Apgar, luaran klinis neonatus dengan feeding intolerance, enterokolitis nekrotikan (EKN), dan penggunaan ventilasi mekanik (nilai $p<0,05$ ).

Kadar IGF-1 ASI Transisi dan HBD-2 Feses Neonatus

Untuk menjawab tujuan penelitian apakah terdapat perbedaan kadar IGF-1 ASI ASI transisi dan HBD-2 feses antara neonatus aterm dan prematur, dilakukan uji komparatif independent t-test (Tabel 2). Hasil analisis statistik pada Tabel 2 menunjukkan perbedaan yang signifikan rata-rata kadar IGF -1 ASI transisi dan HBD-2 feses neonatus aterm dan prematur, dengan perbedaan ratarata masing-masing sebesar $0,726 \mathrm{ng} / \mathrm{ml}$ dan $2130,67 \mathrm{ng} / \mathrm{ml}(\mathrm{p}<0,05)$. Dilakukan analisis statistik untuk mengetahui perbedaan ratarata kadar IGF-1 ASI transisi dan HBD-2 feses dari tiap-tiap kelompok sampel penelitian (kelompok 37-<42 minggu, kelompok 32-<37 minggu, kelompok $28-<32$ minggu, dan kelompok <28 minggu). Perbedaan rata-rata adar IGF-1 ASI transisi dan HBD-2 feses dari 4 kelompok sampel penelitian dapat dilihat dari Gambar 1 dan 2.

\section{Luaran Klinis Neonatus}

Uji komparatif numerik dilakukan untuk mengetahui apakah perbedaan kadar IGF-1 ASI transisi dan HBD-2 feses dari tiap-tiap luaran klinis neonatus yang menjadi sampel penelitian menunjukkan kemaknaan secara statistik. Dilakukan uji komparatif numerik dengan uji independent t-test atau one-way ANOVA. Hasil yang diperoleh dari uji komparatif dapat dilihat pada Tabel 3. Pada Tabel 3 menunjukkan perbedaan kadar IGF-1 ASI transisi yang bermakna secara statistik pada luaran klinis neonatus dengan feeding intolerance dengan mean difference $-0,78 \mathrm{ng} /$ $\mathrm{ml}(\mathrm{p}=0,00)$. Hasil uji komparatif kadar HBD2 feses neonatus menunjukkan perbedaan kadar HBD-2 feses yang bermakna secara statistik pada luaran klinis neonatus dengan feeding intolerance, enterokolitis nekrotikan, dan penggunaan ventilasi mekanik $(p<0,05)$, dan didapatkan kadar HBD-2 feses yang lebih besar dan signifikan pada neonatus dengan luaran klinis patologis. 
Tabel 1. Karakteristik sampel penelitian.

\begin{tabular}{|c|c|c|c|c|c|c|}
\hline \multirow{2}{*}{$\begin{array}{l}\text { Karakteristik Sampel } \\
\text { A. Karakteristik Ibu }\end{array}$} & \multicolumn{4}{|c|}{ Kelompok Sampel } & \multirow{2}{*}{ Jumlah } & \multirow{2}{*}{ Nilai $p$} \\
\hline & $37-<42$ & $32-<37$ & $28-<32$ & $<28$ & & \\
\hline Usia ibu & & & & & & $0,242^{\mathrm{a}}$ \\
\hline 17-35 tahun & 5 & 6 & 4 & 6 & 21 & \\
\hline$>35$ tahun & 1 & 0 & 2 & 0 & 3 & \\
\hline Indeks massa tubuh ibu & & & & & & $0,828^{a}$ \\
\hline $18,5-24,9$ & 1 & 3 & 3 & 4 & 11 & \\
\hline $25-29,9$ & 3 & 1 & 2 & 1 & 7 & \\
\hline$>30$ & 2 & 2 & 1 & 1 & 6 & \\
\hline Pendidikan ibu & & & & & & $0,101 \mathrm{a}$ \\
\hline Sekolah Dasar & 3 & 0 & 1 & 0 & 4 & \\
\hline Sekolah Menengah Pertama & 0 & 1 & 0 & 4 & 5 & \\
\hline Sekolah Menengah Atas & 0 & 1 & 3 & 2 & 6 & \\
\hline Diploma/ Sarjana & 3 & 4 & 2 & 0 & 9 & \\
\hline Pekerjaan ibu & & & & & & $0,721^{b}$ \\
\hline Tidak bekerja/ Ibu rumah tangga & 3 & 4 & 3 & 2 & 12 & \\
\hline Bekerja & 3 & 2 & 3 & 4 & 12 & \\
\hline Paritas ibu & & & & & & $0,144^{b}$ \\
\hline Primipara & 1 & 1 & 2 & 0 & 4 & \\
\hline Multipara & 5 & 5 & 4 & 6 & 20 & \\
\hline Perokok Aktif & & & & & & $0,016^{* b}$ \\
\hline Ya & 0 & 0 & 0 & 3 & 3 & \\
\hline Tidak & 6 & 6 & 6 & 3 & 21 & \\
\hline Pre-eklampsia/Eklampsia & & & & & & $0,000^{* b}$ \\
\hline $\mathrm{Ya}$ & 0 & 5 & 0 & 0 & 5 & \\
\hline Tidak & 6 & 1 & 6 & 6 & 19 & \\
\hline $\begin{array}{l}\text { Preterm premature rupture of membrane/ } \\
\text { Premature rupture of membrane }>18 \mathrm{jam}\end{array}$ & & & & & & $0,065^{b}$ \\
\hline Ya & 3 & 6 & 2 & 2 & 13 & \\
\hline Tidak & 3 & 0 & 4 & 4 & 11 & \\
\hline Korioamnionitis & & & & & & $0,860^{b}$ \\
\hline Ya & 1 & 1 & 1 & 2 & 5 & \\
\hline Tidak & 5 & 5 & 5 & 4 & 19 & \\
\hline
\end{tabular}


Lanjutan Tabel 1. Karakteristik sampel penelitian.

\begin{tabular}{|c|c|c|c|c|c|c|}
\hline \multirow{2}{*}{$\begin{array}{l}\text { Karakteristik Sampel } \\
\text { Karakteristik Neonatus }\end{array}$} & \multicolumn{4}{|c|}{ Kelompok Sampel } & \multirow{2}{*}{ Jumlah } & \multirow{2}{*}{ Nilai $p$} \\
\hline & $37-<42$ & $32-<37$ & $28-<32$ & $<28$ & & \\
\hline Jenis kelamin bayi & & & & & & $0,212^{b}$ \\
\hline Laki-laki & 4 & 1 & 1 & 2 & 8 & \\
\hline Perempuan & 2 & 5 & 5 & 4 & 16 & \\
\hline Cara lahir & & & & & & $0,015^{*} b$ \\
\hline Spontan & 1 & 0 & 3 & 5 & 9 & \\
\hline SCTP & 5 & 6 & 3 & 1 & 15 & \\
\hline $\begin{array}{l}\text { Berat badan lahir (gram), } \\
\text { rata-rata (SD) }\end{array}$ & $\begin{array}{l}3296,00 \\
(454,35)\end{array}$ & $\begin{array}{l}2179,63 \\
(181,70)\end{array}$ & $\begin{array}{l}1264,57 \\
(135,99)\end{array}$ & $\begin{array}{l}899,33 \\
(86,03)\end{array}$ & $\mathrm{n} / \mathrm{a}$ & $0,000^{*} \mathrm{c}$ \\
\hline AS-1, median (min-maks) & $6(6-7)$ & $5(3-7)$ & $5(3-6)$ & $3(1-5)$ & $\mathrm{n} / \mathrm{a}$ & $0,007^{*} \mathrm{c}$ \\
\hline AS-5, median (min-maks) & $\begin{array}{c}7,5(7- \\
9)\end{array}$ & $7(5-9)$ & $7(5-8)$ & $5(3-7)$ & $\mathrm{n} / \mathrm{a}$ & $0,021^{*} \mathrm{c}$ \\
\hline Feeding intolerence & 0 & 1 & 4 & 6 & 11 & $0,002^{* a}$ \\
\hline Enterokolitis nekrotikan (EKN) & 0 & 0 & 1 & 5 & 6 & $0,002^{* a}$ \\
\hline Neonatal sepsis (late onset sepsis) & 0 & 1 & 0 & 1 & 2 & $0,536^{a}$ \\
\hline Ventilasi mekanik & 0 & 0 & 0 & 3 & 3 & $0,042^{* a}$ \\
\hline
\end{tabular}

Keterangan: nilai $p<0,05=$ signifikan $\left({ }^{*}\right)$. a nilai $p$ dihitung dengan uji Chi-square; ${ }^{b}$ nilai $p$ dihitung dengan uji Kruskal-Wallis; dan ${ }^{c}$ nilai $p$ dihitung dengan uji one-way ANOVA.

Tabel 2. Hasil uji independent t-test kadar IGF-1 ASI transisi dan HBD-2 feses pada neonatus aterm dan prematur.

\begin{tabular}{|c|c|c|c|c|c|c|}
\hline \multirow[b]{2}{*}{$\begin{array}{c}\text { Karakteristik } \\
\text { Sampel }\end{array}$} & \multicolumn{3}{|c|}{ IGF-1 ASI Transisi } & \multicolumn{3}{|c|}{ HBD-2 Feses } \\
\hline & $\begin{array}{c}\text { Mean (SD) } \\
(\mathrm{ng} / \mathrm{ml})\end{array}$ & $\begin{array}{c}\text { Mean } \\
\text { Difference } \\
\text { (ng/ml) }\end{array}$ & Nilai $p$ & $\begin{array}{c}\text { Mean (SD) } \\
(\mathrm{ng} / \mathrm{ml})\end{array}$ & $\begin{array}{c}\text { Mean } \\
\text { Difference } \\
\text { (ng/ml) }\end{array}$ & Nilai $p$ \\
\hline $\begin{array}{l}\text { Aterm } \\
\text { Prematur }\end{array}$ & $\begin{array}{l}2,32(0,49) \\
1,59(0,56)\end{array}$ & 0,726 & $0,010^{*}$ & $\begin{array}{c}1246,33(633,27) \\
3377,00(1953,67)\end{array}$ & 2130,67 & $0,017^{*}$ \\
\hline
\end{tabular}

Keterangan: signifikan $\left({ }^{*}\right)$ apabila nilai $p<0,05$

Tabel 3. Hasil uji komparatif kadar IGF-1 ASI transisi dan HBD-2 feses terhadap luaran klinis Neonatus.

\begin{tabular}{lcccc}
\hline \multirow{2}{*}{ Luaran Klinis Neonatus } & \multicolumn{2}{c}{ IGF-1 ASI Transisi } & \multicolumn{2}{c}{ HBD-2 Feses } \\
\cline { 2 - 5 } & $\begin{array}{c}\text { Mean } \\
\text { Difference } \\
(\mathrm{ng} / \mathrm{ml})\end{array}$ & Nilai $\mathrm{p}$ & $\begin{array}{c}\text { Mean } \\
\text { Difference } \\
(\mathrm{ng} / \mathrm{ml})\end{array}$ & Nilai $\mathrm{p}$ \\
\hline Feeding intolerence & $-0,78$ & $0,00^{* a}$ & 2655,66 & $0,00^{* a}$ \\
Enterokolitis nekrotikan & $-0,54$ & $0,067^{\mathrm{a}}$ & 3267,78 & $0,00^{* a}$ \\
Late onset sepsis & $-0,17$ & $0,72^{\mathrm{a}}$ & 493,82 & $0,74^{\mathrm{a}}$ \\
Ventilasi mekanik & $\mathrm{n} / \mathrm{a}$ & $0,08^{\mathrm{b}}$ & $\mathrm{n} / \mathrm{a}$ & $0,03^{* \mathrm{~b}}$ \\
\hline
\end{tabular}

Keterangan: nilai $p<0,05=$ signifikan $\left(^{*}\right)$. a nilai $p$ dihitung dengan uji independent $t$-test; ${ }^{b}$ nilai $p$ dihitung dengan uji one-way ANOVA; n/a: not applicable. 


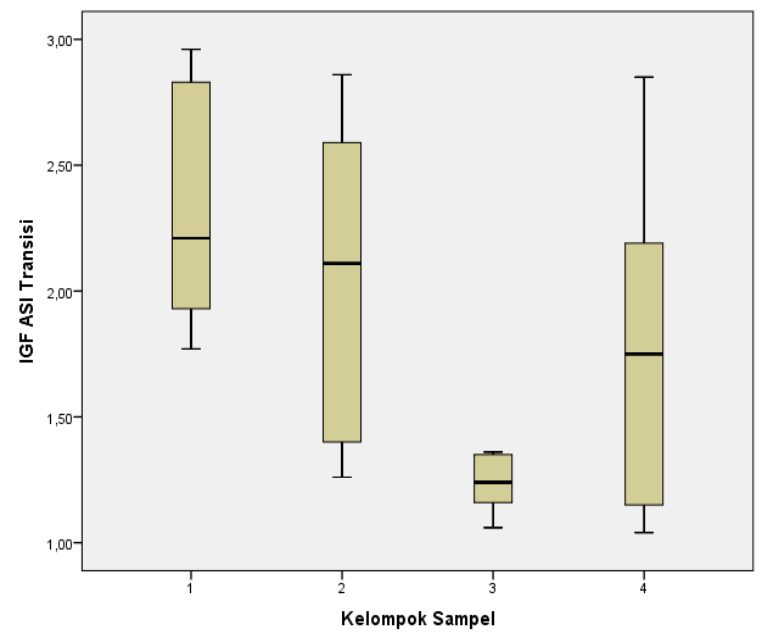

Gambar 1. Rata-rata kadar IGF-1 ASI transisi.

Keterangan: kelompok 1 (37-42 minggu), kelompok 2 (32-<37 minggu), kelompok 3 (28-<32 minggu), dan kelompok 4 (<28 minggu). Rata-rata kadar IGF-1 ASI transisi pada kelompok 1 (37$<42$ minggu) lebih tinggi dibandingkan tiga kelompok lain.

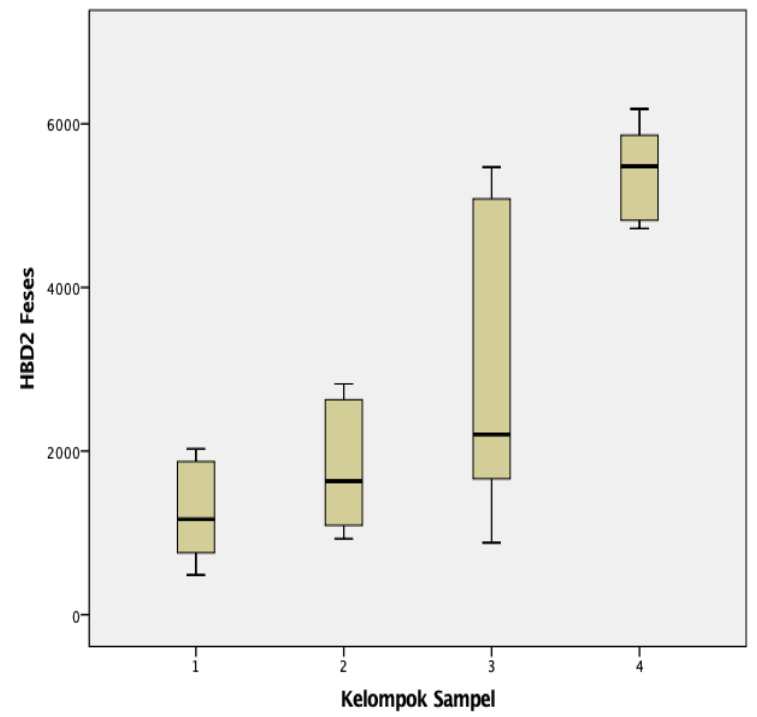

Gambar 2. Rata-rata kadar HBD-2 feses.

Keterangan: kelompok 1 (37-42 minggu), kelompok 2 (32-<37 minggu), kelompok 3 (28-<32 minggu), dan kelompok 4 ( $<28$ minggu). Rata-rata kadar HBD-2 feses pada kelompok 4 (<28 minggu) lebih

\section{Pembahasan}

\section{Karakteristik Sampel Penelitian}

Proporsi empat kelompok sampel penelitian berdasarkan karakteristik ibu yang dianalisis, tidak terdapat perbedaan bermakna secara statitistik ( $p>0,05)$, kecuali pada karakteristik ibu dengan riwayat perokok aktif dan pre-eklampsia/eklampsia. Tiga orang ibu yang menjadi sampel perokok aktif keseluruhannya melahirkan bayi pada kelompok neonatus extremely preterm ( $<28$ minggu). Perbedaan proporsi sampel ibu yang merokok pada penelitian ini bermakna secara statistik $(p=0,016)$. Hasil penelitian ini tidak berbeda dengan penelitian sebelumnya yang menyimpulkan bahwa kebiasaan merokok pada ibu hamil meningkatkan risiko kelahiran prematur, preterm premature rupture of membrane, dan perdarahan pasca persalinan. 18,19 
Karakteristik sampel ibu yang ikut serta dalam penelitian, sebagian besar (19/24) tidak didapatkan riwayat pre-eklampsia/eklampsia, hanya 5 sampel yang memiliki riwayat preeklampsia/eklampsia yang secara keseluruhan melahirkan neonatus prematur. Perbedaan riwayat pre-eklampsia/eklampsia pada sampel penelitian bermakana secara statistik $(p=0,00)$, hasil penelitian ini tidak berbeda dengan beberapa penelitian lain, yang menyimpulkan bahwa pre-eklampsia/ eklampsia memilki hubungan kausatif dan merupakan faktor risiko kelahiran prematur. ${ }^{20,21,22}$

Tujuh dari sembilan karakteristik neonatus yang dianalisis dalam penelitian ini menunjukkan perbedaan proporsi sampel yang bermakna secara statistik $(p<0,05)$. Kelahiran secara sectio cesarean didapatkan pada sebagian besar (15/24) sampel penelitian. Hasil penelitian MacDorman et al., 2014 menunjukkan adanya peningkatan sebesar $47 \%$ kelahiran bayi prematur dengan sectio cesarean dibandingkan kelahiran bayi aterm. ${ }^{23}$ Penelitian kohort oleh Delnord et al., 2014 juga memberikan kesimpulan yang sama yaitu adanya peningkatan prevalensi tindakan sectio cesarean pada kelahiran prematur. ${ }^{24}$ Berat badan lahir neonatus yang menjadi sampel penelitian ini ditampilkan dalam rata-rata $\pm S D$, rata-rata $\pm S D$ berat badan lahir kelompok $37-<42$ minggu adalah $3296,00 \pm 454,35$ gram, kelompok $32-<37$ minggu adalah 2179,63 $\pm 181,70$ gram, kelompok 28-<32 minggu adalah $1264,57 \pm 135,99$ gram, dan kelompok <28 minggu adalah $899,33 \pm 86,03$ gram. Sesuai grafik pertumbuhan janin, hasil tersebut menunjukkan rata-rata \pm SD berat badan lahir sampel penelitian ini sesuai dengan usia kehamilannya (sesuai masa kehamilan/SMK). Penelitian di Taiwan menununjukkan prevalensi terjadinya prematur dengan SMK sekitar 70\% dibandingkan dengan KMK (kecil masa kehamilan) sebesar $30 \%$, dengan angka kejadian KMK bervariasi antara 10-40\% di berbagai negara. ${ }^{25}$ Hasil penelitian ini menunjukkan perbedaan median skor Apgar menit ke-1 dan menit ke-5 pada kelompok neonatus aterm dan neonatus preterm yang menjadi sampel penelitian signifikan secara statistik $(p<0,05)$. Hasil penelitian ini tidak berbeda dengan beberapa penelitian lain yang menyimpulkan skor APGAR yang rendah berhubungan dengan kelahiran prematur, kehamilan multipel, riwayat persalinan sectio cesarean sebelumnya, obesitas pada ibu, dan fetal compromissed.26,27 Analisis statistik menunjukkan perbedaan proporsi kelompok sampel neonatus yang signifikan berdasarkan luaran klinis neonatus (feeding intolerance, enterokolitis nekrotikan, dan penggunaan ventilasi mekanik); keseluruhan sampel neonatus dengan luaran klinis patologis berada pada kelompok neonatus prematur ( $<37$ minggu) ( $p$ $<0,05$ ). Hasil penelitian ini sesuai dengan kesimpulan penelitian lain bahwa prematuritas dan BBLR meningkatkan risiko morbiditas dan mortalitas seperti terjadinya hipoglikemia, feeding intolerence, jaundice, hipotermia, dan risiko sepsis dibandingkan dengan neonatus lahir cukup bulan. 4,28

\section{Kadar IGF-1 ASI Transisi dan HBD-2 Feses}

Dari hasil penelitian didapatkan perbedaan rata-rata kadar IGF-1 ASI transisi dan HBD-2 feses yang bermakna secara statistik pada kelompok neonatus aterm dan prematur; rata-rata kadar IGF-1 ASI transisi kelompok neonatus aterm lebih tinggi 0,726 $\mathrm{ng} / \mathrm{ml}$ dibandingkan kelompok neonatus prematur $(p=0,010)$. Hasil penelitian ini juga membuktikan rata-rata kadar HBD-2 feses neonatus prematur lebih tinggi $2130,67 \mathrm{ng} / \mathrm{ml}$ dibandingkan kelompok neonatus aterm $(p=$ $0,017)$. Analisis statistik lebih lanjut menunjukkan bahwa kadar IGF-1 ASI transisi dan HBD2 feses dari tiap-tiap kelompok sampel neonatus memilki perbedaan rata-rata kadar IGF-1 dan HBD-2 yang bermakna secara statistik ( $p=0,003$ dan $p=0,000$ ). 
Rata-rata kadar IGF-1 ASI transisi tertinggi pada kelompok sampel aterm $37-<42$ minggu $(2,32 \pm 0,49 \mathrm{ng} / \mathrm{ml})$ dan rata-rata kadar HBD-2 feses tertinggi pada kelompok extremely preterm $<28$ minggu $(5425,17 \pm 587,30 \mathrm{ng} / \mathrm{ml})$.

Hasil analisis statistik menunjukkan korelasi yang signifikan antara kadar IGF-1 ASI transisi dengan usia kehamilan $(r=0,611$; $p=0,002$ ). Kadar IGF-1 ASI transisi berbanding lurus dengan usia kehamilan ibu, temuan penelitian yang sama diuraikan oleh Lassarre et al. (1991) bahwa kadar serum IGF -1 dan IGF-2 maternal lebih tinggi dua sampai tiga kali pada kehamilan aterm dibandingkan dengan usia kehamilan $\leq 33$ minggu. ${ }^{29}$ Hasil penelitian lain memberikan kesimpulan serupa, bahwa neonatus prematur memiliki kadar IGF-1 serum rendah dan memiliki hubungan dengan peningkatan risiko retinopati prematuritas dan EKN. IGF-1 menunjukkan efek protektif selama peradangan dan apoptosis yang didorong oleh sitokin. ${ }^{13}$ Hasil penelitian ini berbeda dengan yang dipublikasikan Cooley et al. (2010), menyimpulkan tidak terdapat hubungan yang signifikan antara kadar serum IGF-1 dan IGF2 maternal dengan kelahiran prematur. ${ }^{30}$ Masih terbatas penelitian kohort dengan sampel penelitian pasangan ibu dengan neonatus prematur dan aterm yang mengevaluasi kadar IGF-1 ASI secara serial pada tahapan laktasi mulai dari ASI kolostrum, ASI transisi, dan ASI matur; sebagai data pembanding penelitian kami.

Analisis statistik pada penelitian ini menunjukkan korelasi yang signifikan antara kadar HBD-2 feses dengan usia kehamilan ( $r$ $=-0,725 ; p=0,000)$. Kadar HBD-2 feses neonatus berbanding terbalik dengan usia kehamilan ibu. Penelitian Campeotto et al. (2010), memberikan kesimpulan serupa bahwa neonatus prematur menunjukkan kadar HBD-2 feses yang tinggi pada 15 sampai 60 hari post-natal (82 ng/g; 30-154 \& $85 \mathrm{ng} / \mathrm{g} ; 26$ -390). ${ }^{15}$ HBD-2 merupakan pertahanan lini pertama dalam melawan infeksi dengan menginduksi interaksi antara imunitas alami dan adaptif pada bayi baru lahir. Penelitian terdahulu menunjukkan adanya peningkatan HBD-2 pada mukosa kolon neonatus yang mengalami inflamasi. ${ }^{16}$ Temuan penelitian kontradiktif diuraikan oleh Richter et al. (2010), terdapat perbedaan kadar HBD-2 yang signifikan terhadap usia kehamilan, kadar HBD-2 feses yang rendah merupakan faktor risiko luaran klinis enterokolitis nekrotikan pada neonatus prematur. ${ }^{31}$

Kadar IGF-1 ASI Transisi dan HBD-2 Feses terhadap Luaran Klinis Neonatus

Penelitian ini membuktikan terdapat perbedaan kadar IGF-1 ASI transisi yang bermakna secara statistik pada luaran kinis neonatus dengan feeding intolerance $(p=0,00)$. Temuan penelitian lain menyimpulkan bahwa salah satu faktor pertumbuhan (growth factors) dari ASI yang memilki peran penting dalam patofisiologi enterokolitis nekrotikan adalah IGF-1.32 Hasil uji komparatif kadar HBD-2 feses neonatus menunjukkan perbedaan kadar HBD-2 feses yang bermakna secara statistik terhadap luaran klinis patologis neonatus dengan feeding intolerance, enterokolitis nekrotikan, dan penggunaan ventilasi mekanik $(p<0,05)$. Campeotto (2010), Pang (2014), dan Corebima (2017) memberikan kesimpulan serupa, didapatkan peningkatan kadar HBD-2 feses dihubungkan dengan infeksi saluran pencernaan pada neonatus, yang membuktikan peran potensial HBD-2 feses sebagai biomarker EKN. 15,16,17

\section{Keterbatasan Penelitian}

Terdapat beberapa keterbatasan dalam penelitian ini, jumlah sampel yang kecil diperoleh secara consecutive sampling dapat mempengaruhi representasi sampel penelitian terhadap populasi umum. Pengukuran parameter IGF-1 ASI dan HBD-2 feses dilakukan satu kali pengukuran, sehingga tidak dapat diketahui pola perubahan kadar IGF-1 ASI dan HBD-2 feses pada periode neonatal. 
Penelitian ini tidak mengukur kadar serum variabel IGF-1 dan HBD-2, sehingga tidak diketahui variabilitas biologis kadar IGF-1 dan HBD-2 yang menjadi keterbatasan penelitian.

\section{Kesimpulan}

Terdapat perbedaan bermakna kadar IGF-1 ASI transisi dan HBD-2 feses dari tiaptiap kelompok sampel penelitian, kadar IGF-1 ASI transisi berbanding lurus dengan usia kehamilan dan sebaliknya kadar HBD-2 feses terhadap usia kehamilan. Terdapat perbedaan kadar IGF-1 ASI transisi lebih rendah bermakna pada neonatus dengan feeding intolerance dan kadar HBD-2 feses lebih tinggi bermakna pada neonatus dengan luaran klinis patologis (feeding intolerance, enterokolitis nekrotikan, dan penggunaan ventilasi mekanik).

\section{Saran}

Perlu dilakukan penelitian lanjutan yang melakukan pengukuran serial variabel kadar IGF-1 ASI dan HBD-2 feses, sehingga dapat diketahui pola perubahan kadar IGF-1 ASI dan HBD-2 feses pada periode neonatal. Kadar serum IGF-1 dan HBD-2 perlu diukur untuk mengetahui variabilitas biologisnya. Perlu dilakukan. penelitian yang lebih komprehensif, mengevaluasi karakteristik klinis ibu yang dapat mempengaruhi produksi ASI, growth factors, dan AMP (asupan nutrisi, status imunologis, penyakit kronis prekonsepsi, dan sebagainya), kadar hormonal dan atau substrat lain yang mempengaruhi kadar IGF-1 ASI (IGF-2, IGFBP, GH, prolaktin, estradiol, dan sebagainya), serta kadar HBD-2 feses neonatus (pola mikrobiota saluran pencernaan neonatus).

\section{Daftar Pustaka}

1. Eidelman Al and Schanler RJ. Breastfeeding and the Use of Human Milk. The American Academy of Pediatrics. 2012; 129 (3):e827-e841. doi:10.1542/peds.20113552.
2. Denning PW and Maheshwari A. Necrotizing Enterocolitis: Hope on the Horizon. Clinics in Perinatology. 2013; 40 (1):xvii-xix.

3. World Health Organization. Born Too Soon: The Global Action Report on Preterm Birth. Geneva: WHO. 2012.

4. Camacho-Gonzalez A, Spearman PW, Stoll BJ. Neonatal Infectious Diseases: Evaluation of Neonatal Sepsis. Pediatr Clin North Am. 2013; 60(2):367-89.

5. Soeorg H, Huik K, Parm U, IImoja ML, Metelskaja N, Metsvaht T, Lutsar I. Genetic Relatedness of Coagulase-Negative Staphylococci from Gastrointestinal Tract and Blood of Preterm Neonates with LateOnset Sepsis. Pediatr Infect Dis J. 2013; 32:389-393.

6. Trend S, Strunk T, Lloyd ML, Kok $\mathrm{CH}$, Metcalfe J, Geddes DT, Lai CT, Richmond P, Doherty DA, Simmer $\mathrm{K}$, and Currie $\mathrm{A}$. Levels of Innate Immune Factors in Preterm and Term Mother's Breast Milk During the 1st Month Postpartum. British Journal of Nutrition. 2016; 115:1178-1193.

7. Strunk $T$, Doherty $D$, Richmond $P$, Simmer K, Charles A, Levy O, Liyanage K, Smith T, Currie A, Burgner D. Reduced Levels of Antimicrobial Proteins and Peptides in Human Cord Blood Plasma. Arch Dis Child Fetal Neonatal Ed. 2009; 94(3):F230 -1. doi: 10.1136/adc.2008.143438.

8. Goldenberg RL, Culhane JF, lams JD, Romero R. Epidemiology and Causes of Preterm Birth. Lancet. 2008; 371:75-84.

9. Bishara R, Dunn MS, Merko SE, \& Darling P. Volume of Foremilk, Hindmilk, and Total Milk Produced by Mothers of Very Preterm Infants Born at Less Than 28 Weeks of Gestation. Journal of Human Lactation. 2009; 25(3):272-279. 
10. Bachour P, Yafawi R, Jaber F, Choueiri E, Abdel-Razzak Z. Effects of Smoking, Mother's Age, Body Mass Index, and Parity Number on Lipid, Protein, and Secretory Immunoglobulin A Concentrations of Human Milk. Breastfeed Med. 2012; 7 (3):179-188.

11. Hassiotou F, Hepworth AR, Metzger P, Ching TL, Naomi T, Hartmann PE, Filgueira L. Maternal and Infant Infections Stimulate a Rapid Leukocyte Response in Breastmilk. Clin Transl Immunol. 2013; 2 (4):e3. doi: 10.1038/cti.2013.1. eCollection 2013 Apr.

12. Dizdar EA, Sari FN, Degirmencioglu $H$, Canpolat FE, Oguz SS, Uras N, Dilmen U. Effect of Mode of Delivery on Macronutrient Content of Breast Milk. J Matern Fetal Neonatal Med. 2014; 27:10991102.

13. Ballard O, Morrow AL. Human Milk Composition: Nutrients and Bioactive Factors. Pediatr Clin North Am. 2013; 60(1):49-74.

14. Avula S, Smith LN, Monga R, Lockwood L, Kadrofske M. Stool Biomarkers to Diagnose Necrotizing Enterocolitis in Preterm Infants: A Pilot Case-Control Study. Pediatrics. 2017; 140(1):1-7.

15. Campeotto $F$, Baldassarre $M$, Laforgia $N$, Viallon V, Kalach N, Amati L, Butel MJ, Dupont C, Kapel N. Fecal Expression of Human Beta Defensin 2 following Birth. Neonatology. 2010; 98:365-369.

16. Pang T, Leach ST, Katz T, Day AS, Ooi CY. Fecal Biomarker of Intestinal Health and Disease in Children. Front Pediatr. 2014; 2(6):1-12.

17. Corebima BIRV, Rohsiswatmo R, Gayatri $P$, Patole S. Fecal Human Beta Defensin2 (hBD-2) Levels and Gut Microbiota Patterns in Preterm Neonates with Different Feeding Patterns. Iranian Journal of Microbiology. 2019; 11(2):151-159.

18. Kyrklund-Blomberg NB, Granath F, Cnattingius S. Maternal Smoking and Causes of Very Preterm Birth. Acta Obstet Gyne- col Scand. 2005; 84(6):572-7.

19. Ion RC, Wills AK, and Bernal AL. Environmental Tobacco Smoke Exposure in Pregnancy is Associated with Earlier Delivery and Reduced Birth Weight. Reprod Sci. 2015; 22(12):1603-11. doi: 10.1177/1933719115612135. Epub 2015 Oct 27.

20. Davies EL, Bell JS, and Bhattacharya S. Preeclampsia and Preterm Delivery: A Population-Based Case-Control Study. Hypertens Pregnancy. 2016; 35(4):510519. Epub 2016 Jun 20.

21. Rasmussen $S$, Ebbing $C$, Irgens LM. Predicting Preeclampsia from a History of Preterm Birth. PLOS ONE. 2017; 12(7): e0181016.

22. Samani RO, Ranjbaran M, Amini P, Esmailzadeh $A$, Sepidarkish $M$, \& Hashiani AA. Adverse Maternal and Neonatal Outcomes in Women with Preeclampsia in Iran. The Journal of Maternal-Fetal \& Neonatal Medicine. 2019; 32(2):212-216.

23. MacDorman MF, Matthews TJ, Mohangoo $A D$, Zeitlin J. International Comparisons of Infant Mortality and Related Factors: United States and Europe, 2010. Natl Vital Stat Rep. 2014; 24:63(5):1-6.

24. Delnord $M$, Blondel $B$, Drewniak $N$, Klungsøyr K, Bolumar $F$, Mohangoo A, Gottvall K. Varying Gestational Age Patterns in Cesarean Delivery: an International Comparison. BMC Pregnancy and Childbirth. 2014; 14(1):1-9.

25. Tsai LY, Chen YL, Tsou KI, Mu SC. The Impact of Small-for-Gestational-Age on Neonatal Outcome among Very-Low-Birth -Weight Infants. Pediatr Neonatol. 2015; 56(2):101-7.

26. Hegyi T, Carbone T, Anwar M, Ostfeld B, Hiatt M, Koons A, Pinto-Martin J, and Paneth N. The Apgar Score and Its Components in the Preterm Infant. Pediatrics. 1998; 101:77. 
27. Svenvik M, Brudin L, and Blomberg M. Preterm Birth: A Prominent Risk Factor for Low Apgar Scores. BioMed Research International. 2015; Article ID 978079:8 pages.

28. Natile $M$, Ventura ML, Colombo $M$, Bernasconi $D$, Locatelli A, Plevani C. ShortTerm Respiratory Outcomes in Late Preterm Infants. Italian Journal of Pediatrics. 2014; 40:52.

29. Lassarre C, Hardouin S, Dafos F. Serum Insulin-Like Growth Factor Binding Proteins in the Human Fetus. Relationships with Growth in Normal Subjects and in Subjects with Intrauterine Growth Retardation. Paediatr. Res. 1991; 29:219-225.
30. Cooley SM, Donnelly JC, Geary MP, Rodeck $\mathrm{CH}$, Hindmarsh PC. Maternal Insulin-Like Growth Factors 1 and 2 (IGF1, IGF-2) and IGF BP-3 and the Hypertensive Disorders of Pregnancy. $J$ Matern Fetal Neonatal Med. 2010; 23 (7):658-61.

31.Richter M, Topf HG, Gröschl M, Fröhlich T, Tzschoppe A, Wenzl TG, Köhler H. Influence of Gestational Age, Caesarean Section, and Type of Feeding on Fecal Human Beta-Defensin 2 and Tumor Necrosis Factor-Alpha. J Pediatr Gastroenterol Nutr. 2010; 51(1):103-5.

32. Tanner SM, Berryhill TF, Ellenburg JL, Jilling $T$, Cleveland DS, Lorenz RG, and Martin CA. Pathogenesis of Necrotizing Enterocolitis. Modelling the Innate Immune Response. Am J Pathol 2015; 185: 4-16. 